\section{CULTIVATING THE GARDEN \\ OF THEATER CULTURE: A NEW PERSPECTIVE ON TRADITIONAL THEATER IN THAILAND ${ }^{1}$}

\section{Pornrat Damrhung ${ }^{2}$}

\begin{abstract}
After questioning the conventional distinction between traditional and modern theater in Asia, this essay suggests that it may be more fruitful to view today's live theater traditions as part of a garden of theater culture that includes both native and imported elements and both deep-rooted and recently transplanted traditions. The remainder of the essay amplifies this perspective using examples from Thailand's theater traditions during the last century and a half. This prepares the way to consider the strengths and weaknesses of traditional theater staged in Thailand during the last decade or so, whether centered on juxtaposing various artistic forms onstage or performing artistic reinterpretations of traditional stories. In seeking to strengthen these approaches for future performances,
\end{abstract}

${ }^{1}$ An earlier draft of this essay was prepared for the International Conference on Asian Traditional Arts, held in Hanoi, Vietnam, sponsored by the Ford Foundation, October 2729, 1998, and a summary of this draft was published in Vietnamese Studies 34.4 (Jan. 1998): 101-111..

${ }^{2}$ Assistant Professor, Department of Dramatic Arts, Faculty of Arts, Chulalongkorn University the author suggests the need for pooling the discipline and creativity performers have in order to fashion patterns of artistic expression that convey significance both among artists and to their audiences.

\section{Introduction}

Traditional theater is a process of interaction between people and their culture more than a fixed institution or commodity. ${ }^{3}$

${ }^{3}$ Scholars in recent decades have clarified the idea of tradition. They no longer presume tradition to be the unchanging cultural foundations of a people or the constant background against which change may be measured. Neither do those familiar with specific traditions see them as the unquestioned repository of cultural value and authenticity. Students of folklore, anthropology and contemporary culture emphasize the traditions they study as the dynamic way that people imagine their past, both to learn about themselves in the present and to shape what they may become in the future. The essays edited by Arjun Appadurai, et al. 1994 are good examples of this new view. After assessing the central claims of this new research, the editor concludes (1994: 22) that tradition is best seen as a "reflective and reflexive" way for "societies [to] explore the 
This interactive perspective on theater is as true for each live performance as it is for all the theater traditions of a place, time and people. Traditional theater, when seen in this way as a cultural process, is dynamic and varied. It has undergone remarkable changes in Asian countries during the last century. Enriched by the wider inclusion of cultural material from countries and companies from around the world, it has also adjusted to pressures from profitseeking media industries, educational bureaucracies, and government cultural policies that have come into play in the last few decades. While the new enrichments have become part of older theater traditions,

limits of their histories, and [to] replay the points of tension in these histories." Rather than a scarce commodity requiring hoarding and protecting, tradition is better seen as a "renewable resource" that helps people to locate themselves in the time and place of their culture. As with all renewable resources, it is important to stress which groups control their performance and articulation.

This essay understands "traditional theater" as the living - vital, unpredictable, uncertain, and vigorous - traditions of live-unrecorded and interactive-performances that theater practitioners and audiences find meaningful today. To help stress "traditional theater" as a cultural process, this paper will view it through three key relationships: 1) the interaction among performers onstage, 2) the interaction between onstage performers and their audiences, and 3) the shared understanding - developed over a long period of time - of both performers and audiences regarding the story, theme, aims, and staging of performances. These three dynamic characteristics, I believe, present us with a better way of understanding "traditional theater" in today's Asian societies. the latter pressures have sought to cast the cultural processes that constitute traditional theater into unchanging and reproducible forms with specific values.

The enrichments and pressures affecting traditional theater in recent decades are often at odds with the place and significance of theater traditions for their creators and audiences. Rather than seeing productions primarily as renewable and marketable products with universal appeal, many of those involved in the dynamic, uncontrollable, and interactive process of traditional theater value it as public entertainment that informs social identity and solidifies local culture.

A century ago, live theater traditions in Thailand entertained the royal court and nobility, new groups of middle class merchants in Bangkok, and the people of local communities. ${ }^{4}$ Today, more elaborate and sophisticated educational, cultural, and commercial forces do most of the shaping of

\footnotetext{
${ }^{4}$ See Surapone Virulrak 1999. At the end of the reign of King Rama V (King Chulalongkorn) in the early twentieth century, there were many private theaters built in the palaces of princes and princesses and the villas of the aristocracy. They gave public performances of dance drama either in the classical styles of Lakhon Nai or Lakhon Nok or in modernized variations, such as Lakhon Phantang, Lakhon Rong, and Lakhon Dukdamban. Among the best-known private theaters were Chao Phraya Thewetwongwiwat at Ban Mo Palace, the Prince Theater of Chao Phraya Mahintharasakdhidamrong, and Pridalai Theater of Prince Narathip Praphanphong at Phang Nara Palace (Rutnin 1993: 220).
} 
Thai theater traditions. Most productions are staged with support from state agencies, commercial mass media companies, and various national or foreign organizations. None are profit-making ventures. The powerful and sometimes conflicting forces arrayed in this new institutional environment now often influence theater traditions and performances more than the ties that these traditions have to the lives and concerns of their local audiences and the surrounding living theater culture.

To understand deep-rooted theater traditions, scholars need to assess how the above forces shaped their current configurations in society. This research will help to understand how rich old forms of drama and classical literature change to continue entertaining and exciting today's audiences. Those involved in promoting live theater traditions for tomorrow's audiences likewise need to respect our current repertoire of traditions and become more aware of how and why they have become what they are.

This essay suggests an approach that will allow both disciplined performers and learned scholars to share their creativity and knowledge in new ways in order to help Thai traditional theater thrive. In particular, I want performers and scholars to seek for ways to ensure that Thailand's live performance traditions remain a vital part of their audiences' lives outside the constraints of bureaucratically imposed cultural uniformity and profit-making entertainment. The resources, personnel and aims of universities provide one good base for those interested in achieving these larger goals, but they must work together with government agencies, private companies, and individual artists. From that base and others, those interested in ensuring the vitality of live theater traditions into the next century need to envision Thailand's rich theatrical heritage in new ways and also creatively adapt current traditions so that they can entertain and challenge today's audiences.

Toward this end, I liken the enriching cultural process of traditional theater to cultivating, and see those who do this work as laboring in the garden of theater culture. After relating this general view to Thailand's traditions and discussing the changing environment within which Thai traditions developed, this essay will suggest that the plants in its garden of traditional live performance culture are more like adaptable cultural staples than exotic ethnic fruits to entertain audiences in unchanging ways. I then go on to suggest some alternative ways for those interested in the survival of live theater traditions to achieve their aims.

The perspective of cultivating theater culture adopted in this essay asks performers and scholars to creatively respond to today's changing environment and to look for ways to make theater traditions part of people's lives. Without the outlines of a shared understanding between performer, scholar, and audience, traditional theater can never be a meaningful part of people's lives. Live theater has been a vital part of people's lives for centuries and the vital interaction between a people and its culture is in no danger of dying. The 
only question is what kind of live performances will be part of this interaction in the future. That depends on what kind of live theater we choose to cultivate.

\section{Toward a New View of Traditional Asian Theater: From Exotic Entertainments to Live Performances}

Many earlier accounts of theater traditions in Asia have stressed their formal aspects that outside observers found most striking. These accounts have often come at the expense of emphases on their rich and complex meanings for performers who made them and the audiences who enjoyed and sponsored them. Because the significance of these forms is rarely self-evident, it can be better assessed when the traditions that embody this significance are seen in the historical flows that shaped them. Historians now regularly acknowledge that Asian societies have been an integral to the world's historical flows for millennia. Their trade and exchanges have contributed to the formation of the more integrated world in the past few centuries, including its cosmopolitan theater traditions. Asia's integration with and future contributions to the changing world are likewise undisputed.

The study and practice of theater has also been part of the flow of Asia's history in the last hundred years. During this time scholars have changed how they understand Asian performance traditions, even as these traditions have themselves changed. Studies of "traditional" Asian theater earlier this century often focused on live performances that were seen as examples of exoticism, whether seen in rural areas (mostly viewed by anthropologists) or in the court (mainly observed by royalty and aristocratic embassy officials). Many earlier scholars have subdivided the broad class of "traditional theater" into classical and popular traditions. This classification system allowed these mainly Westerntrained writers to distinguish native traditions in foreign parts of the world from "modern" theater traditions imported from prosperous Western countries. Such a simple use of the traditional/modern distinction ignores the fact that "traditional" Asian theater made many significant contributions to the creation of "modern" theater in wealthy nations during the twentieth century. It also obscures the fact that many aspects of Western performance traditions have become integral parts of Asian theater traditions during this century. When explored in any depth, these facts together with others, make it easy to see that "traditional" and "modern" are generic rather than descriptive terms and may not be the most insightful way to characterize the theater traditions around us today.

If the live theater traditions of Asian countries do not naturally divide into those that are "traditional" (i.e. native, including some mix of classical and popular traditions) and those that are "modern" (i.e. often synonymous with "Western"), it may be fruitful to ask whether there is an alternative approach to characterizing today's theater traditions. I suggest in the next section, that it may be more helpful to view the theater traditions of a time, people and place as a cultural garden. Each garden 
of theater culture emerged over a long period of cultivation, cross-pollination, and grafting by the efforts of many individuals and groups with different kinds of interests in theater productions. This horticultural imagery permits us to admit several facts often ignored in general discussions of theater. The key feature of all of these facts is the realization that live theater is a dynamic relationship between performers and audiences, negotiated through the give and take surrounding actual performances. These negotiated, dynamic relations embody aspects of culture at the same time as they enrich the people and the culture forming these relationships.

This essay will divide the living ground of traditional theater culture into three main plots. First, most Asian countries have, in the past half century, enriched their garden of theater culture by adding Western dramatic arts to themselves: to university curricula, to the repertoire of urban theater companies, to imported performances by foreign troupes, usually through the support of foreign institutions or international organizations, and, through the wide and impressive reach of Western media, to some local theater traditions. Second, classical theater traditions of Asia have survived either by becoming government agencies or through substantial private support, while popular traditions have continued to depend on local or regional support. Third, the narrow segment of Asian societies (mainly urban university-educated people) who support both "modern" and "classical" theater traditions often do not admit their dependence on local or regional popular performance traditions for their vitality. Yet these local vital traditions have survived, adapted, and often thrive by continuing to move rural audiences and garner local support, as well as creating (often profitable) niches for themselves in the mass media (channeled through the television, film, and recording industries).

Although presented separately, all three of these plots have been part of an open and dynamic social and economic landscape for much of the last century. They continuously interacted and modified themselves, and were never closed systems or practice and performance as often suggested by the assumptions of "traditional." Whatever their substantial and enduring aesthetic value and intrinsic beauty, each of them has either adapted to the changing social, cultural, political, and economic environment or withered away into near oblivion.

Popular theater traditions-which are selfsupporting and self-producing-remain the foundations of many features now part of modern and classical performance in many Asian countries. Since their survival depended on the direct and lasting appreciation of their audiences more than lobbying government officials, convincing patrons of a project's value, or demonstrating to a business their profitability, popular theater traditions are still the most innovative and flexible of Thailand's live theater traditions.

As in many Asian countries, Thailand's social and political changes have exposed its citizens to Western education, economy, and culture. Classical dance-theater and modern drama have remained primarily within the 
cultural orbits of new urban middle class college-educated people. This was also true of modern forms of spoken drama, which remain confined mainly to well-educated people in cities. Popular and folk theater traditions, by contrast, remained centered in local communities, from whom they received their support and toward whose tastes they molded their performances.

These three different plots have become the knowledge base from which Asian performing artists and practitioners do their work and create performances today. Because all artists live in a changing society and in a vibrant world, none of their traditions has been able to keep from changing as a discrete cultural package. Instead, each artist, troupe, and tradition has had to question how best to perform his or her art for contemporary audiences. The varied approaches to these questions allowed the artistic work to change while still gripping audiences' hearts and minds.

The theater traditions that have become characteristic features of Asian countries in the last hundred years may conveniently be subdivided into three interrelated clusters:

1) court-based or classical traditions often struggling to maintain old language along with formal dance and musical styles; 2) troupe-based vernacular traditions rooted in local or regional society that typically adapted their performances to their sponsoring audiences; and 3 ) imported traditions, mainly from Western countries that appeal mainly to university educated audiences in urban areas. Since all three of these clustered traditions have been part of the theater experience of Asian countries for most of this century, they are all, by this time, "traditional." The three existing clusters of traditions have been interacting and reshaping each other for nearly a century, even as they have been reshaped by larger social, economic, and political forces. Moreover, although they emerged from very different social and cultural sources and have survived via different priorities and systems of support, these live performance traditions are better seen as part of a complex common, though changing, substrate of unmediated expressive interactions between performers and audiences. For these reasons, this essay will treat traditional theater as live performance traditions that may or may not be distinct from performances often classed as modern (those imported from socially advanced and wealthy countries, which often lack a clear plotline and are abstract). They depend on their proximity to the means and ends of the mass media, commercial interests, and government agencies.

Much of the theater in Asia that existed before interactions with Western countries intensified about a century and a half ago was grounded in set forms structured around well-known stories whose flow followed the tempo and forms laid down by well-trained musicians in musical theater. Those sponsoring performances ranged from the nobility - especially the king in the courtand wealthy patrons in the countryside and in cities. Practitioners in these traditions were very adept at creating visually powerful and musically rich theater in order to present audiences with general moral 
lessons or refined emotional sensibilities. Their skills at ensemble work and narrative presentation, moreover, allowed them to center their work on the making of fluid pieces in which spectacular visuals, wellknown stories and speeches, and set dance forms circulated around adapted standard stories and subtle musical orchestration. The flow of these pieces shifted from scene to scene, whose end was marked by a frozen pose of their central characters. While these forms and stories differed from place to place, and changed over time, there are some overlaps across Asia. This paper will look at Asia through examples taken from Thailand, since its culturally complex past and perpetually uncertain future have made large imprints on theater and mark it as open, diverse, and dynamic as Asia itself.

In the long period of cultural transformation during this century, artists, practitioners, and new audiences have increasingly come to base their expectations, aims, and values on mass appeal encouraged by national cultural models and corporate sponsorship. Yet artists involved in the government cultural agencies and the commercial mass media industries have realized that there are monetary rewards to be mined for pop culture from the pits of classical and folk traditions. This helps explain why recent generations of performers-who often let costumes, sets, and theater techniques hide the lack of discipline and ability to concentrate-often retain the main formal structures of the traditional arts. Unable to come up with something appealing which is new, they fall back on the tried and true ways of moving audiences, ways that are easy to replicate and ways that are more commercial than permitted earlier this century.

\section{The Garden of Thailand's Theater Culture}

In Thailand, the three plots of theater traditions mentioned above (roughly classical, Western and popular) are the concrete forms through which the processes of traditional theater expressed itself. Together, they constitute the three main parts of what I call the garden of Thailand's theater culture. Each has strengths and weaknesses in how it creates live pieces for the stage. And while the divide between spontaneous live theater and edited composites that can be recorded is far from sharp or complete, they do mark a distinctive performance space. This paper argues that cultivating the garden of Thailand's traditional theater cultureusing the full range of theater culture, including modes of training, performance, experience, expectations, and expertisecan only take place through a diverse range of activities by people in all areas and social strata. These activities also have to consider the contemporary constraints and possibilities of live performances and creating different venues where those involved in live performances can coordinate their activities and interact with each other in new ways.

Each cluster of traditions and its practitioners has their strengths. They are too often left unstated or underemphasized because their indirect interactions do not normally demand emphasis. Their individual strengths and weaknesses become clearer 
once they are placed alongside each other in particular performances. Based on experiences of interaction among forms and performers, classical dance-drama (both old and modernized forms) is at its best when its performers demonstrate their focused and concentrated discipline by acting out the subtle and deeply meaningful stories that praise the greatness of classical royal figures and institutions amid musical ensembles. It also indirectly distributed moral and religious teachings for centuries.

Popular theater, by contrast, is best at lively comic and musical pieces based on the well-honed skills of local artists. Its strengths lay in the unique knowledge of each individual artist that continues to excite audiences with the particularities of local artistic and cultural traditions. These artists also showed spontaneous reactions to audience responses that permit the release of tensions produced by living in a world with few possibilities for advancement through expressions of satire against the central government, local issues in community and household comedies of manners. While older performances mocked the foibles of the nobility and royalty, today's performances lampoon politicians and corrupt officials. Modern drama is at its best when it presents other ways of live performance that provoke new ways to think about life and society. By directly presenting audiences with situations that are often disguised or diffused in other types of performance, modern theater challenges audiences to think critically about similar situations in their own lives, while also entertaining them. But since edification and entertainment have long been the prime motivations of Thai theater, the critical aspects of modern theater have yet to root themselves firmly in Thai audiences.

Theater practitioners in Thailand and other parts of Asia need to reflectively change the kinds of work they do, not only to survive, but also to thrive. Many educated people in Asia want to improve their lives with better technology, a richer material life, and better health similar to those in wealthier countries. Achieving these laudable goals often comes through abandoning the specific values of their venerable traditions, including strong discipline, historical relevance, and spiritual depth. We see this changing in some areas, however. More and more perceptive people are seeing development not simply as an unstoppable process of accumulating economic wealth and technical expertise, but as a complex movement that draws people's attention to their unique circumstances in order to better prepare them for the move ahead. As part of this change of perspective, people increasingly realize that without promoting native cultural traditions such as theater, simple economic and technological expansion will remain impoverished.

Because the new lifestyles and cultural priorities that came to dominate modern society were so different from those that underlay the dramatic arts of a century ago, they completely transformed the aims, tastes, and approaches of theater practitioners. Not only have many practitioners lost the meaningful contact with old traditions; they have also only superficially absorbed new and foreign traditions. For these reasons, contemporary practitioners have to search for approaches 
that both revitalize the best of old traditions and strengthen the best in new traditions. For both sorts of performers, it is essential that they make use of the whole repertoire of theater resources available to them in order to stage productions that meaningfully communicate with today's audiences.

\section{Historical Background}

The garden of Thai theater culture changed in the last century and a half along with changes in Thailand's political and social spheres. ${ }^{5}$ These changes fall into two main periods: the eight decades of rule that culminated in the end of absolute monarchy in 1932 and the seven shaky decades of democratic government since that time. Besides being the last reign of absolute monarchy, the reign of King Rama VII also marks a symbolic cultural shift of emphasis from the patronage and interest in theater culture to the patronage and emphasis on the new mass culture exemplified by films. ${ }^{6}$

The classical traditions originally performed at the court, popular traditions performed for communities mainly in rural areas, and imported or hybrid ones performed mainly

5 Mattani M. Rutnin's Dance, Drama, and Theater in Thailand is the most detailed book giving details and reasons for these changes until around 1970, and I rely heavily on her research in this section.

${ }^{6}$ Whereas earlier kings in the Chakri dynasty wrote plays and set up theaters and schools for classical dance-drama traditions and other drama traditions, King Prachathipok wrote scripts for films, directed films and set up a large movie theater to mark the $150^{\text {th }}$ anniversary of the Bangkok period (Virulrak 1999: 77). for the urban educated and mercantile elite form the basis of Thai theater. While the basic forms of these three clusters of traditions changed, they also maintained continuities. In the eight decades after 1851, various forms of dance-drama and theater gradually emerged, combined and reorganized amid big changes in Thailand's society, economy, and government. While society continued to change after 1932, attempts to create meaningful theater have generally failed to make a secure niche for themselves outside of government bureaucracies, corporate interests and the new film culture. More recently, the culture of television has become more popular among the general populace. Theater productions also absorbed aspects of these mass media and cultural industries.

For most of the period of the Bangkok kings, classical dance-drama was centered in the Inner Court and an exclusive and sacred prerogative of the royal family. Various royal efforts in the first periodencompassing the reigns of King Mongkut (Rama IV, r. 1851-1868), King Chulalongkorn (Rama V, r. 1868-1910), King Vajiravudh (Rama VI, r. 1910-1925) and King Prajadhipok (Rama VII, r. 19251932) - resulted in modifications and new codifications of dance-theater traditions that remain standard to this day. Despite some changes, during this time the royal family had the exclusive right to use the drama texts in the Ramakien, Unarut, and Inao in theater productions.

In the politically unstable and socially complex environment within which theater traditions have circulated since 1932, free 
markets and universal education have not been able to encourage much innovation or institution building. They have been able, through widely distributed motion pictures and television programming, to reach audiences around the country with a wider repertoire of entertainments. Theater work in the last seventy years has contributed to a proliferation of new opportunities for entertainment and cultural enrichment, as well as a gradual erosion of old standards, and a basic inability of theater companies to either touch audiences or try new approaches.

Since 1932, the prerogative to use the above three classical drama texts has been transferred to the Department of Fine Arts. Classical dance-drama is now part of this branch of the government bureaucracy, which is charged with being the sole legitimate guardian of Thai culture. Classical traditions of Khon (masked dancedrama) and Lakhon (classical dance-drama) altered their forms at the same time as a new dramatic literature arose that was suitable to the people of the time. Besides borrowing stories from Burma and China, these theater traditions also created productions based on contemporary romantic literature, as well as famous plays from Western countries. ${ }^{7}$ All of these changes appealed to the new middle class and university educated elites who sought entertainments fitting of their new wealth and social prestige. This process of

7 For a translation of King Rama IV's royal decree in 1861, see Rutnin 1993: 263-264, n. 25-26. She discusses its significance on pp. 7578. For the importing of stories from Burma and China and Western countries in classical theater, see Pattrachai, et al. 1997: 11-13. expansion also permitted new motifs and stories from Western drama to enter Thai society in unprecedented ways, often mediated through films, television programs and videos.

In the early part of this century, change in theater was guided by the vision of insightful kings eager to glorify their regimes. The base for classical traditions in the king's Inner Court limited the performance of these stories to a small and sophisticated audience, and ensured a uniform high quality to the performances. While King Mongkut decided to re-establish Lakhon Nai (female dance-drama of the inner court) for royal ceremonies, he also allowed female dancers to teach and dance outside of the court. He continued to maintain a tight hold on its three main sources. This was all part of a royal decree in 1861. Besides making a new center for drama in the court, it also made court traditions more available for the general public. This opened up dance-drama to the changing world and made theater more business-like. ${ }^{8}$ A series of decrees sought to revive the court's dance-drama traditions.? This was not just a way of glorifying his reign, but also a way of counteracting what he thought were excessive cultural influences from European countries. His success can be judged by the fact that the completely revised and updated scripts he ordered for his court performances are still

\footnotetext{
${ }^{8}$ Rutnin, 1996: 79-80.

${ }^{9}$ For a broad overview, see Virulrak 1999: 73 74. For a more detailed analysis see Rutnin 1993: 69-88. Translations of the tax laws for various theater practitioners of Mongkut may be found in Rutnin 1993: 89-92.
} 
the standard models for today's classical performances.

The reign of King Chulalongkorn marked a highpoint of innovative theater in Thai theater. He not only supported many classical troupes, whether they were inside or outside of the court, but also wrote scripts for them. Equally important were the pool of creative writers and actors who experimented, modified, and expanded the uses of drama techniques and practices from Western countries in their plays. This resulted in the creation of whole new genres of drama still used today. The modes of adapting dramatic texts, composing music, production styles, make-up, costume, and scene designs established for classical forms remain standard to this day. ${ }^{10}$

When Chulalongkorn's son, King Vajiravudh, took to the throne, he started a training school in classical dance drama taught by court dancers and opened it to children from all walks of life. Although mainly remaining confined to the court, the king wrote plays and used the theater to teach democratic ideas and constitutionalism to the nobility. He also established these schools in local areas where he had built palaces in various provinces. ${ }^{11} \mathrm{He}$ also wrote new plays for

${ }^{10}$ During Chulalongkorn's reign, many in the royal family and the nobility adopted various Western techniques into classical dance-drama. These forms included Lakorn Dukdambam by Prince Naris, Lakorn Panthang by Prince Chao Phraya Mahin and Lakorn Rong by Narathip (see Rutnin 1993: 117-147; Pattrachai, et al. 1997: 11-14; Virulrak 1999: 74-75).

${ }^{11}$ Rutnin 1993: 168-178; Damrhung 1998: 9-10. classical theater. Theater changed because of the closure of casino theaters that had been hotbeds of innovative forms in the previous eighty years and the introduction of western films to wealthy audiences in Bangkok. ${ }^{12}$

During the reign of King Rama VII, the responsibility for preserving classical traditions moved from the court to the bureaucracy and became a concern of the middle class concerned with maintaining a strong national identity. Continuity with earlier traditions was maintained when former court dancers became the first teachers of classical drama for the new Department of Fine Arts. They not only established the curriculum and methods of instruction that continue to be used today at this institution, but they also preserved the air of superiority for their art. The national network spun from this single repository of dramatic finery into the national education system ensures uniform stylistic standards of their students. Its bureaucratization and search for mass appeal, however, have helped it lose the subtlety and refinement of court dancers in favor of public education and entertainment. ${ }^{13}$

Even before the end of absolute monarchy, new cultural trends began appearing. As part of his personal interest in new technology and new cultural forms, King Rama VII built a large movie theater for the public and wrote scripts for and directed three films. ${ }^{14}$ At the same time, the court

\footnotetext{
12 Virulrak 1999: 76

${ }^{13}$ Pattrachai, et al. 1997: 56.

${ }^{14}$ Virulrak 1999: 77.
} 
came to have less influence on theater traditions than it had in the past.

During this time, initiatives of the court influenced both classical and local performances. They also had an impact on new urban theaters and touring companies in the countryside. New patrons, mainly rich nobles, opened new theaters and inaugurated new dance and drama forms from that time. They often based their repertoire on classical or folk performances that were greatly influenced by foreign performance styles such as spoken drama, musicals, and operettas.

Changes in folk performance traditions were also assisted by King Rama IV's royal decree of 1861, which allowed women dancers to leave the court and privately perform or teach outside it. For many years female theater troupes became more popular since their labor as actresses was cheaper and more easily trained. They were also usually able to do other jobs in the theater troupe such as costumes and make-up. They became more popular, performing all kinds of dance-drama forms, resulting in a situation that made it more likely for the existence of all-women theater-troupes later on. Male dancers gathered together and created a new form of folk theater, called Like' (also transliterated as Likay). ${ }^{15}$ While the origins of this form are uncertain, some

\footnotetext{
${ }^{15}$ It took many years for Likay to develop into the independent performance genres we now recognize as Likay. Although often discussed, the diverse roots and development of Likay are still unclear. They developed as a mixture of information from various sources. Poomsiri 1990; Virulrak 1997.
}

say it arose from influences from Persian chants or Malaysian prayers. Whatever its origins, Liké quickly became a more lively and vigorous genre that is quite energetic, fast-paced, and uses beautiful costumes and sets. Looser in form than its classical counterparts, Liké still borrows some aspects from these genres, while being more flexibly related to the audience and to its repertoire of plots and standard pieces. For many decades, Like' has been played with both male and female performers, and developed into a melodramatic form based on new literature and dress more like that of ordinary people today rather than basing itself on the dress of the classical theater.

Moreover, after the end of absolute monarchy in 1932, one of the new democratic governments absorbed all of the arts and culture groups that had formerly been part of the royal court. ${ }^{16}$ Classical Thai theater shifted from its former base in the king's court, becoming part of the new state bureaucracy. Some of the handpicked royal performers in classical Thai dance-drama were asked to found the Academy of Dance and Music in 1934 for the training of the next generation of performers, and later fixed a national curriculum for all prospective performers in the classical traditions. This curriculum and some of those who crafted it became the foundations of the new National Fine Arts Department (FAD), which has remained the single national center for classical courtbased dance-drama traditions to the present day.

\footnotetext{
${ }^{16}$ Rutnin, 1993: 238.
} 
Another important site for their interaction was the school system, which was based on the educational system promoted in Western countries. Moreover, since 1932, schools have introduced students to the vocabulary, ideas and practices of democracy, just as buying things has introduced them to market capitalism. This has helped introduce recent generations to democracy and economics.

From this time, Lakhon has had more places for performance in society. The democratic government has used both traditional dancedrama forms in classical and more popular genres as badges of Thailand's cultural depth or to educate the general populace. The FAD determined the new standards of dance-drama and musical theater based on those used by the French government.

\section{Luang Wichitwathakan was} assigned by the premier [Phibun] to create a totally new theater, completely detached from the old regime... [He] modernized lakhon ram [dance-drama proper] through the use of modern music, contemporary dialogue, and historical costumes appropriate to the periods of the plays such as lakhon phan thang [multiethnic dance-drama], instead of the classical costumes. In short, he made practical use of a combination of aspects from lakhon dukdamban [classical dance-drama operetta], lakhon phan thang, lakhon rong [Thai operetta], lakhon phut [spoken drama] all of which were first developed in the Fifth Reign, and brought them up to date, so that they could be presented at the national level. His nationalistic and periodical plays not only entertained (surprisingly they still do in their recent revivals), but also brought forth a very strong and effective political message. ${ }^{17}$

As some Thai artists toured Western countries, they came back to Thailand and incorporated what they had seen and learned into sets and costumes, as well as theater techniques in the FAD. This went on to gradually influence popular theater troupes as well. These new elements also included modern theater forms that encompassed both classical dance-drama in modernized forms and styles and straight plays in prose and poetry on contemporary social and political themes. ${ }^{18}$

Both within and outside the school system, popular culture, reshaped and often guided by the commercialized mass media has reinforced ideas of progress centered on raising standards of living, and the accumulation of capital, technological devices, and technical expertise.

All of this has often been to the detriment of those areas of society unable to demonstrate their ability to raise capital or contribute to the technical advancement of their countries that nonetheless contribute to the quality of peoples' lives. In this area one would have to include the forms and practitioners of live performance. The other alternative was to weave Thai elements of theater and culture into Western performances in order to make them more appealing to Thai audiences.

\footnotetext{
${ }^{17}$ Rutnin, 1993: 191.

${ }^{18}$ Rutnin 1993: 197.
} 
Thus, some productions reduced the amount of dancing in order to enhance postured acting, or adding spoken drama while reducing songs, or adding Western musical instruments or a Western storyline to the production.

Most traditional theater pieces, whether popular or court based, had a common structure. Using a limited set of character types and a limited repertoire, theater troupes construct their performances differently than those typical in Western theater. Basic plots were selected from long classical or popular narratives, staged as scenes which culminate in still pictures reminiscent of Thai temple murals, along with some special transitional scenes, whose flow is always structured by set musical forms. Among the changes one notices in theater productions from a century ago (in comparison with earlier productions for the court) are the following:

CHANGES IN PLOT \& STORY: Besides staging shorter pieces of Khon and Lakhon based on older and longer performances, performing troupes also reduced the complexity and subtlety of the plots based on old stories in order to attract less refined audiences. But shrinking the length of the pieces and simplifying their plots were accompanied by a greater concentration on the activities of a single character instead of the actions of an ensemble. ${ }^{19}$ Moreover,

${ }^{19}$ Interview with Ajarn Seri Wangnaitham of the FAD (now retired) in March 1989 about new scripts for khon (masked-dance) for educational purposes. The khon episode called Hanuman Charn Samorn (Hanuman, the Great warrior), concentrated on the whole life of the single there is now a tendency to emphasize the theme of the piece. Today, most visitors to FAD productions are foreigners and school children, so the current emphasis is on educating audiences using standardized ways of performance rather than innovation. This transformation of dance-drama replaced the old classical forms, and most of the productions were now based on the modernization made in the last sixty years. These changes created what we now know as Lakhon (dance-drama). Productions by FAD were called Lakhon even though they used new modernized scripts from Lakhon Phanthang and Lakorn Dukdamban, which were new styles and quite different from the old forms of classical drama. The new productions were divided into scenes and always ended within three hours. Classical Khon at the FAD has continued earlier traditions by only performing scenes from the Ramakien, while Lakorn Nai at the FAD continues to only perform scenes from Ramakien, Inao and Unarut. The FAD performs Lakorn Nork using the script of King Rama II as background for its plots. This tradition has lost its vitality for more than sixty years, with one scene performed once every three years or so as a museum show piece rather than a living tradition.

CHANGES IN TECHNIQUES: From free outdoor performances only on special occasions as earlier in this century, dancedrama has been influenced by many

character Hanuman. Ajarn Wangnaitham selected Hanuman because young people identify with this trickster-hero monkey. The script was rearranged to allow young students to know the character and his life at the same time as they learned about classical theatrical traditions. 
traditions from foreign (mainly from Western) countries. One of the biggest changes has been the performance on indoor stages. The move indoors affected the lighting, sets, costumes and orchestras. Indoor settings required more careful thought about the use of lighting to generate different effects. Those planning the scenery now had to consider more carefully the construction and painting of indoor sets. New kinds of costumes came to reflect the wider cultural foundations of Thai theater, including new costumes for Burmese, Chinese, Laotian and Western characters. These costumes also tended to use less decoration and embroidery. After moving inside, music became softer and singing became less narrative description and more focused on emotion and meaning. There was also a greater use of spoken theater techniques and less use of classical theater, and greater use of comic improvisation. Microphones and sound manipulation devices also changed how sound fit into the productions. Performing troupes in the last seven decades have made greater use of Western sets and lighting. The pieces onstage are now more spectacular and visually impressive because they depend on a wider variety of visual stimuli than just the costumes in earlier times, including the use of disco lighting and laser lights. They also now tend to highlight a single character, probably because the performance spaces and audiences have increased in size.

CHANGES IN MUSIC: Productions began using many more kinds of musical instruments and musical styles in productions. Performances sometimes use Western orchestras in their plays, leading to a greater mixing of musical forms and dance styles. $^{20}$ New musical instruments and performing were developed to create better effects in this new auditorium. Audiences are more familiar with spoken theater and the use of theater to promote and teach new information. It gradually made Thai theater culture more similar to spoken theater and realistic acting. Different kinds of dances and new choreography were added and combined with new musical forms.

While Thailand's oldest theater traditions are grounded in local society and the central court, they have long interacted with traditions from foreign (especially Western) countries. While some of these traditions have been based on direct experience with live performances (mostly popular music but also theater), during the last thirty years a majority of the influences from Western countries have come through the general distribution of films, television programs, and musical recordings.

\section{The Current Situation}

Like a century ago, we are now in the midst of a time of great social and cultural change. Thailand is experiencing rapid and largescale cultural invasions at the same time as the global reverberations from the explosion of our smallish bubble economy have begun

${ }^{20}$ Interview with Ajarn Jaturong Montrisart, lecturer in Witthayalai Natasin in February 1999 on attempts to modernize the traditional pieces. $\mathrm{He}$ gave as an example the piece Chantakinnaree staged in the 1970s using ballet dance and music for the Kinnaree human bird within the traditional dance-drama performance. 
to quiet as the society heads toward an uncertain future. People have woken up to an unanticipated, but real, discomfort, as well as new possibilities. They have also begun looking for new foundations for their thinking and action. Some have seen returning to our roots as the optimal way ahead, while others have sought to become better integrated into the global environment. Theater scholars and practitioners not only have much to learn from theater elsewhere in the world, they also have much to learn about Thai theater culture.

The appendix to this essay lists more than thirty collaborative productions done in the past fifteen years that worked to communicate with today's audiences using familiar stories and forms in new ways. Some reinterpreted old stories from Thai classical and folk literature for today's society or adopted foreign scripts to Thai theatrical sensibilities. Others focused on juxtaposing various theatrical forms or styles onstage. These two general approaches expressed themselves in classical, popular and modern imported theater traditions in different ways. In seeking to preserve unchanged classical stories and forms, the FAD has often lost the heart and the depth of the pieces they performed, so that they do not touch today's audiences. By adapting their rich and lively traditions to the dominant commercial and mass media environment and the star system in order to survive, popular theater genres have simplified their productions and tamed their comic improvisations, weakening their critical wit and sharp political sarcasm that had been key aspects in earlier times. Productions based on modern theater have sought to narrate Western stories with emotional patterns familiar to Thai audiences without seeking to challenge their senibilities and provoke them into new thoughts and feelings.

Despite the shortcoming of these approaches, I am still cautiously optimistic about the future of traditional theater in Thailand and Asia. Traditions now part of our popular theater - such as Liké, Lakhon

Thai (female dance-drama) Morlum (competitive singing from Isaan) and Nang Talung (small shadow-puppet theater from southern Thailand) - which have shown that there are many ways for live theater to survive in contemporary Thai local communities still have much to teach. ${ }^{21}$

${ }^{21}$ The folk performance of Like is wildly popular live entertainment in many provinces, as well as through the media of TV, videos and cassette tapes. A simpler variant of this form is called Lakhon Thai, danced and sung only by women. It is still practiced in Petchaburee and Nakorn Prathum provinces. Although sponsored mainly for thanking the spirits (called Lakhon kabon) for their fulfillment of something prayed for, it is also used for simple entertainments (Pattrachai, et al. 1997: 38-39; 59). Morlum is a loose and improvisational type of interactive folk singing with many performance centers in Isaan provinces and wide distribution throughout Thailand via radio, TV and recorded music. More recently a new kind of Morlum called Morlum Zing has become popular with young people. Adopting a pop concert format, complete with sexy costumes worn by the main performers and backup singers, this style uses a quicker rhythm and electric pop music bands including guitars and drums, u like traditional morlum that just used the kaen (reed organ). Nang Talung is a type of shadow puppet still 
These popular traditions have already been strenthened by their participation in global flows of culture through telecommunications and travel and these will have greater impact in the future. Besides maintaining strong links to local society and adapting to the world of mass media, our popular traditions are actually thriving and well-liked by large sections of the population. They thrive outside the view of most "theater people" in cities, who seek to promote the immature modern and static classical traditions of Thai theater.

Positive signs also appear from these latter quarters. Those strongly grounded in classical dance-drama traditions and those trained in modern drama have been renewing their search, in the past decade, for new ways to attract and hold the next generation of theater-goers. Both modern and classical performers have been experimenting, collaborating and adapting their skills in innovative ways. Even so, they are still several steps behind popular theater troupes, that have survived because of their continued ability to entertain their sponsors and audiences, which provide them their livelihoods.

Changes in the last decade have made traditional performances shorter, quicker, and strongly centered on visual and musical aspects of the production. Although still quite inflexible in their approach to training performers and appealing to audiences, the

used in local communities of south Thailand. Although often using dirty jokes and light humor, the head of the troupe often intersperses performances with various witty criticisms of politicians and political issues.
FAD has succeeded in making classical traditions known throughout the country and abroad, whereas a century ago they only appeared in the central court. Today, pieces performed by the FAD regularly use spoken theater in classical performances. ${ }^{22}$ They also have removed some transitional scenes from traditional performances that did not move the story along. Moreover, they have begun emphasizing universal ideas within plots organized around conflicts that also entail transitions from a beginning to a middle and end. The FAD rarely performs tragic pieces, since audiences prefer happy endings and patrons prefer endings in which good is shown to triumph. Some performers have also begun to play their characters more expressively and individually. ${ }^{23}$ Although $\mathrm{FAD}$ productions make greater use of plot centered on conflicts and obstacles, they do not deal with conflicts in the western sense. Most productions are still organized as narrative pieces centered on short, intense dance scenes that indicate a turning point in the narrative. While conflict and obstacles do occasionally lead to climaxes in renditions of classical theaterpieces today, the movement of the piece is

${ }^{22}$ See appendix \# 5 (Phuchanasipthit).

${ }^{23}$ In the 1997 Patravadi Theater production of "Sahatsadeja" the role of the mother Montho played by Patchara Buathong with Pichet Klunchuen as her giant-son Intrachit projected much sadness toward her son, which is very unusual for traditional Khon productions (appendix \# 18). Traditionally, even those who do not wear masks should behave as though wearing a mask and keep their faces still. (P. Damrhung, "Nimitmai Lakhon Ruem Samai," Krajok Maya, Krungthep Turakit February 14, 1997). 
still largely in the service of a narrative centered on stylized acting based on conventional forms of emotional expression. This reduces traditional ways of learning to their lowest common denominator, so students simply imitate the superficial forms of their teachers, while failing to embody what is genuine and powerful in these traditions.

The difficult task of theater practitioners today is to learn better ways to recognize and use the essential strengths of the particular genre they have come to master, and then to create works that continue to show the genuine beauty and profound themes of traditional works. We also need to stage traditional and contemporary performances in ways that are balanced and clearly show the heart of the tradition.

Because of the neglect for the heart of traditional performance in productions by the FAD, modern Khon and old forms of Lakhon Nok (folk male dance-drama outside the court) and Lakhon Nai (female dancedrama of the inner court) have continued to be performed. These performance traditions have tried to preserve the patterns of individual masters in a bureaucratic setting. This has led to training and productions that have become stiff forms that serve as museum pieces usually without the heart of their former traditions.

Besides the vital popular traditions and the stagnant classical traditions are performances that attempt to bridge the two, often using contemporary performance formats and contemporary themes. This approach adapted traditional items for plays designed for the contemporary stage. ${ }^{24}$ This more experimental work has performers try to bring together different forms onstage. The method of juxtaposing different forms is about as adventuresome as is possible with most audiences here, since they still prefer entertaining spectacle and excitement in productions more than challenges and provocation. For this purpose performers use traditional stories, since they are more entertaining and are better known to Thai audiences than foreign plays. Moreover, they are usually presented as fantastic and far removed from ordinary life, making it quite easy to create new forms for different characters. Recent examples of this type include the King and the Bird-Princess, the Golden Deer, the Rooster Spell, and the Giant. All of these classical figures can easily be dressed up as characters that could be Western ballet dancers or contemporary Western dancers in traditional Thai dancedrama. $^{25}$

Juxtaposing distinct styles within a given scene or performance is an easy and effective trick which still has possibilities in

\footnotetext{
${ }^{24}$ Many old stories that criticized various set characters have been revived and updated in new theatrical settings in order to be appropriate for today's audiences. There has been as interest in women's characters, such as Khaki, Pimpilalai and Savitri (See appendix \# 3, 6, 7, 16, 17, 25). Old stories have also been revived and updated to deal with various issues such as democratic selection, abuse of power, and contemporary family problems (See appendix \# 4, 7, 11, 19, 24, 25).

${ }^{25}$ Interview with Ajarn Jaturong Montrisart of the Fine Arts Department February 1999.
} 
Thailand. ${ }^{26}$ This is because audiences are somewhat familiar with each different form and are excited by seeing them side-by-side onstage. Audiences like it because it gives them a sense of being part of the modern world while still somewhat familiar to them. In this way, it is an apt metaphor for their contemporary life in Thailand. It works because audiences are excited by pieces still based on spectacular and exciting forms.

Combining traditional and contemporary musicians and composers also works through juxtaposition. These productions merge various rhythms and melodies based on the soul of the music but are also not afraid of synthesizers and technology. Modern musicians still have much to learn from the rhythms and the sense of the traditional music, just as traditional musicians can learn more by playing alongside synthesizers to get the spirit of the production. In Thai theater, music sets the atmosphere and the tempo of the production, and gives the performance life. Musicians

26 The earliest production of this type was "Kamupathan Khaki," directed by Janaprakal Chandrueng in 1993 (appendix \# 6). It used Julchart Arunyanark to dance the Garuda part in a classical style before he turns into a handsome playboy in the next scene. He continued this in "Nithan Vetal" (appendix \# 14). "Love and Death" directed by Pornrat Damrhung in 1996 (appendix \# 17) extended this approach with Pichet Klunchuen dancing as Yama, Lord of the Dead in classical Thai style, juxtaposed by modern dancer (Nuchavadee Bumrungtrakul), a ballet dancer, and a spoken theater actor. This was continued by the later "Love of Khaki" (appendix \#21). are concrete and work things out more easily than others.

Recent productions have begun to make more use of new forms of technology. From large-scale set and lighting design to slide and film projections, productions both classical and contemporary still have much to learn from this in Thailand. Technological innovation has begun to influence the designs and the looks and the length of productions. ${ }^{27}$

All of this can be easily done in productions here, since most Thais want to create a productions that speaks more directly and meaningfully to their audiences with the tools of performance they have on hand. The foundations of Thai taste in theater seek to:

A. show that Thai audiences look at theater as entertainment that presents audiences with a view that good moral behavior is the best way to behave in society. Thailand's theater arts center on the design - onstageof a series of static scenes that resemble Jataka tales painted in temple murals, moving from one scene through a wellknown story. Each scene culminates in a moment when the hero or his counterpart appears in a positive or negative situation, and marks a greater or lesser turning point in the larger frame story. The production then moves on to the next scene, which is

27 Multimedia uses of film and video in productions, as well as audience participation, have been effectively used by Katsura Kan in a collaborative piece based on an Isaan folk story with support from the Japan Cultural Center and Patravadi Theater (appendix \# 22). 
organized in the same way. However many scenes are performed in a production, at the end of a performance, the hero is always victorious. This happy ending allows audiences to take a virtuous lesson away from the production while enjoying the beautiful changing scenes onstage. In this way, Thai theater pieces often resemble slide projections of performers representing an episode in the life of a hero. This helps to make sure that stories are performed onstage in a wonderful and exciting way. ${ }^{28}$

B. Folk and regional theater performances seek to entertain those who have worked hard in the fields. For them theater is a way to boost their spirits. Lighthearted and humorous pieces allow them to laugh or become excited and have a good time at the end of a long day of work. Although these entertainments often use dirty language and naughty behavior, they still end with a strong reminder of established patterns of morality. The hero or the one who behaves morally earns recognition, victory, or reward. This is one of the reasons Thai audiences like to see shows with a happy ending: it confirms the importance and the value of a moral life. Thus we often see theater-pieces with entertaining music and dance pieces with spectacular sets and costumes. More recently these costumes and sets explicitly take their cue from the international world of business suits, glamorous worldwide stars, and the lifestyles of the globally rich and famous,

28 The Patravadi Theater has produced many spectacular musical theater pieces based on traditional Thai stories and often including traditional Thai music and dance (see appendix \# $8,12,13,18)$. and usually includes more decoration. All of this gives pleasure to the audience and allows them to go home happy. Native theater forms still make use of foreign music and dance steps as part of their performances in ways that audiences still accept. ${ }^{29}$ Many of these performances no longer develop their satiric power and wit, choosing instead to conform to a sanitized world dominated by non-offensive publicity agents that will ensure that they will be able to generate a regular revenue. The wide availability of television programs has given audiences a taste for the glitzy and apolitical. Folk performances conform to safe forms of comedy and current fads about who and what is sexy.

C. Using modern technology or familiar things from today's world in order to hint that what is onstage is also contemporary. This has not been used much in Thailand, but I believe that it would be well accepted since it has the marks of modernity. These uses have typically borrowed from things seen at Western cabarets, from Western music concerts and videos, and from popular international films. Recently some

29 While researching folk theater, the author found that Like performers in Chainat dressed in a bodysuit and with hair and sunglasses like Michael Jackson just after he played his concerts in Thailand during his world tour in 1995 (Pattrachai 1997: 42-44). Many Liké performances also include western muscial pieces and improvisational comic sketches with allusions to events in Western countries. There are also transvestites playing roles of comic actors and dancers in Liké productions, often acting like a jealous woman. 
have also begun to use laser lighting to liven up Khon productions.

The above changes omit the lively power that structured and vitalized traditional theater. They also ignore some things that rarely appeal to audiences:

A. productions that leave audiences with an uneasy feeling or unsure about the progress or outcome of the production. Audiences do not want to see a production for its capacity to provoke them into thinking, whether about their own lives or about the production itself. While Thai theater genres have some tragic stories, they are not very popular with audiences, and so are rarely shown onstage. When they are shown onstage, they stand as examples of bad behavior or are presented in highly revised or edited forms. Presenting death onstage, for instance, has never been possible in Thai theater, since it is considered bad luck. Many productions have shied away from sharp social satire and political criticism.

B. productions that peel away all the decoration to focus on the interaction between actors onstage or the theme. This allows actors onstage to state things plain and clear. ${ }^{30}$ In Thailand, lobbying and compromising are important parts of presenting the theater arts. This shows up in how pieces appear onstage. They are put onstage with a narrative style with stylized conflict and fighting, and where no bad people end up winners. Western theater

30 The experimental collaboration NONTOOK done at Chulalongkorn University in January 1998 (appendix \# 25) focused on the unbalanced power relations between social classes. productions often center around conflicts between protagonists and antagonists, man and nature, man and fate, or one human being against another.

C. productions that concentrate on unpleasant or controversial themes such as social divisions, political disagreements, criticisms of religion, or human conflict. While all of these themes exist in traditional forms, they are always implicit or subtly represented so few can understand what is happening.

D. productions that focus on the actor and his abilities and talents to communicate with the audience, both his specific knowledge and his unique approach to deal with his job, minus his forms and decoration. Audiences would be shocked to feel the power of direct confrontation and would feel uncomfortable by it.

Thai audiences regularly compliment popular performance with the word "sanook" (fun) and show their approval for classical productions with the word "swei" (beautiful). Creating pieces that fulfill these expectations is the the main focus of performers and directors. Nonetheless, most dance-drama and musical genres have survived in the last century by adapting themselves to the new social, political, economic, and cultural environment, and gradually adopting imported (mostly from wealthy Western countries) techniques into Thai performances that have altered earlier ideas of fun and beauty. As new ideas refocused the purpose and structure of education, it has become more acceptable and desirable to see productions with 
themes related to technology, science and art, which have permitted Thai audiences to enjoy these productions more. Farces, comedies, and musicals from foreign countries have fared the best before Thai audiences. $^{31}$

Some of those trained in traditional arts want to search for new ways of staging classical productions that will be clear and beautiful, and that speak to younger audiences in fun ways. They usually simplify the art in order to make it easier to look at and more natural to the modern world. They abandon the difficulty of their art and the concentration required for the traditional forms in order to focus on insignificant decoration and formal aspects. The growing expectation of easy art and instant stardom has also contributed to the erosion of the value of classical training. All of this has helped to lower the standards of those who choose to become involved in these difficult arts. The soul of classical training, especially its strong discipline and the uncertainty of a future career, often gets lost in petty competition for a better spot in the bureaucratic pecking order. Less circumspect audiences trained on quickpaced TV shows in which camera angles, lighting, makeup, and good editing can erase flaws and make everyone seem more perfect than they are, also contribute to lowering expectations among the classically-trained.

The world of the next century will continue to shrink as it has been in the last five centuries. People will continue to be exposed to a much wider range of artistic

\footnotetext{
${ }^{31}$ Pattrachai, et al. 1997: 58-60.
}

forms and styles through better telecommunications and travel technologies. ${ }^{32}$ But while passive exposure is valuable, it will not by itself lead to better understanding or to new attempts to make traditions live. This exposure must accompany interaction and involvement by both audiences and practitioners of the theater. These hold out the hope of doing something new with our grand old traditions in the new millennium. New hybrid forms will arise from various projects that take advantage of these better technologies and enhanced exposure. ${ }^{33}$ While we still have

32 There have already been attempts in the building of international exchanges and collaborative ventures such as the the ASEAN Drama Festival (1989-1994), the ongoing AsianPacific Performers Exchange (APPEX) (1996present) and the Inroads/Asia at UCLA (1997) conference, and various ventures sponsored by the Japan Cultural Center. For example, the latter has supported the "Akaoni" project (19981999), which used a Japanese director and Thai actors to perform in both Japan and Thailand. The Japan Cultural Center also sponsored the production of King Lear in 1997 that had artists working together in different forms and styles to perform one production with a director from Singapore (using Noh and Chinese Peking opera artists and a contemporary dancer from Thailand).

${ }^{33}$ The Makhampom Educational Touring Theater Company has worked in Thailand for nearly two decades, mixing traditional elements of Lahon Ram (classical dance) and various folk musical pieces and stories into their performances, always around themes of social concern. They have used theater to help reach children facing the problems of drug use, prostitution, AIDS, among other topics (see appendix \# 8, 11). Various discussions and interviews with Pradit Prasartthong 1994-1999. 
much to learn from the living traditions in each country, theater practitioners must work together in international venues on works aiming to make something familiar but innovative using the cultural materials around them.

To date, juxtaposing forms and styles or showcasing individual performers has been the norm in cultural exchange. ${ }^{34}$ In the future, flexible and inquisitive performers will blend their art more subtly with others into hybrid forms that audiences in both rural Thailand and American cities can enjoy and appreciate. ${ }^{35}$

In addition, the theater artists will also have to continue exploring the role and meaning of human beings and technology in their pieces, and consider the place of art in contemporary society, and the possibilities for social and cultural change. To be effective, this explorer's sense must be

34 "Love and Death" in 1996 (appendix \# 17) was an example of this. Pichet Klunchuen and Sumon Rongrueng Silpa collaboated on a dance based on a Lakhon Phantang story in 1998 (appendix \# 29). "The Death of Empedocles," a joint French-Japanese-Thai performance in June 1999 (appendix \# 31) gave a more sophisticated way of mixing cultural traditions. At the APPEX workshop at UCLA in June- August 1999, the classically-trained Thai dancer Pichet Klunchuen and a contemporary American dancer familiar with Indonesian traditions performed a dance of an Indonesian folk love story (apendix \# 32). Interview with P. Klunchuen, August 1999.

${ }_{35}$ The experimental collaborative piece NONTOOK, first performed in Bangkok and at Inroads/Asia UCLA in August 1997, and again in a more stripped down and experimental piece in January 1998 suggested one approach to more integrative collaborations (appendix \# 25). rooted in a specific place, time, perspective, tradition or theme, or the cultural tools with which to do the collaborating will be lost. Once contact with tradition, history and culture are lost, it will no longer be possible to make sense of their strengths to enrichand alter-the contemporary world.

In today's world, collaboration means artists focus whatever skills and talents they have to create the best possible project they can. Some of these skills might have been gained from training in classical or folk theater and other skills from learning Western drama. The main point is that these practitioners are willing and able to contribute them to the ensemble work. At present it is often difficult to maintain pure boundaries between different theater genres. Many kinds of performers are onstage at the same time, working to move audiences. Those at the performances are also not easily divided, since they have gone through the same school system and live with the same mass media and social organizations.

The task of traditional theater practitioners today is to search for and master the core and essential aspects of each genre. By core aspects, I mean the features that performers can use to entertain, move, and challenge audiences. It is important that traditional theater be allowed to remain fun, while also developing its capacities to affect the heart and mind.

The importance of collaborative projects toward this end cannot be stressed enough. They allow people to coordinate and fuse together larger visions of what becomes possible by weaving together traditional 
forms, dancers, stories, techniques, music, and visions for contemporary theater. These new traditional performances will no longer simply be ethnic works for various cultural ghettos or ethnic enclaves. If the traditional arts are not to lose their effectiveness in educating the younger generation, money, time, and hard work are no less necessary than heart, skill and will. Such efforts can be used to enhance national pride and remind people of the truth of being human. They have to allow disciplined performers to communicate the heart of their art directly with their audience.

There are many ways-besides those that already exist - for the traditional theater-arts to thrive in contemporary Thailand. I find two of these ways the most promising. First of all, we should concentrate more on mining and refining the rich stories and themes for today's stage pieces. To do this, theater artists need to examine more carefully the piece they are staging to discover what motivates and resolves their main turning points. Another good exercise is to consider the relationships of these pieces to today's society. For centuries, Thailand's performance traditions have made places for themselves in Thai society and culture. By continuing to use the creative energies of today's practitioners, they will be able to creatively evolve toward the future in ways that do not neglect their past. Old stories and plots are too often left divorced from the ordinary pressures and possibilities of people's everyday lives. Yet they can be used as lenses to explore similar situations or circumstances in the contemporary world. They can help performances preserve the essence or heart of old performance traditions while making it new for today's performers and audiences.

Another way of approaching traditional performance genres today is to strip away the outer layers of story and spectacle that have accrued and solidified in recent decades, returning to their core themes, movements, and forms. By deleting the nonsensical and superficial aspects of traditional theater, and returning to purify its essential core, contemporary performances can both delight and challenge today's audiences. It is important to return to the heart of dance-drama in order to allow its simple and elegant strength to show itself onstage. For well-prepared artists, this removes them from the ethnic ghettos to which they have been assigned by critics and cultural managers, and opens them up to more genuine forms of interaction with other ways of artistic expression. Audiences, too, will be able to appreciate and learn from such performances since they will be able to see traditional dance in a purified form usually only available in rehearsals. The chief aspect of traditional dance that such an approach to performance will be able to convey is that its power resides not in the fancy costumes, makeup, lighting, and sets, but rather in the strong discipline and concentration of the performers. This will also permit young performers to develop healthier attitudes to their performance and young audiences who are able to understand the meaning of tradition to their ordinary lives. 


\section{Future Possibilities and Priorities}

Performances that reinterpret old stories in new settings and juxtapose various performance styles are now commonplace on Thai stages. By focusing on preserving classical forms (FAD theater), commercially-viable styles (popular theater like Liké) or narrating modern stories centered on set emotional patterns (Western theater), recent theater performances have often lost sight of the purpose of their performance: namely, to communicate something meaningful and unexpected to their audiences.

Those interested in making theater in Thailand stand at a crossroads. Instead of facing the false, but easy, choice between whether to preserve the cultural forms, styles, and patterns they inherited or to modernize them, theater practitioners must struggle to find out how best to entertain and challenge audiences with the arts that they know. There are two broad strategies to begin searching toward this new openended choice. On the one hand, those interested in theater have to think more critically and perceptively about the theater traditions they know in order to more effectively communicate the meaning of their performances to themselves and their audiences. On the other hand, they have to clarify their strengths and weaknesses in relation to theater traditions from other places and times to take their place in our global culture in order to communicate more effectively with people who grew up in different circumstances than they did.
The garden of theater culture has both deep roots and lush branches. Learning to appreciate and care for the whole garden and for all the plants in this garden, from the tips of their roots to the tops of their branches is the main aim for scholars and practitioners of theater in the future. Preliminary results from those who have begun probing these two strategies in the last decade are promising but still immature (see appendix). These practitioners have laid the groundwork for new future performances that are grounded in the traditions they call their own, but also open to the traditions known better in other parts of the world of which they live here and now. They have returned to the fundamentals of focused ensemble acting in which decoration, spectacle, and stardom are secondary and dramatic turning points and direct communication with themselves and with their audiences are central.

While recent examples of reinterpreting old stories and juxtaposing set forms have been promising, they are still immature. New and more profound approaches are needed. The time has come to consider the place and purpose of each of familiar stories, spectacular sets and costumes, and set musical and dance forms for the contemporary stage. Performers and audiences may respond better to unfamiliar stories, less showy (or less familiar) costumes and sets, and more open-ended collaborative projects, leaving the standard repertoires to those who specialize in them in the FAD, theater troupes and some university dramatic arts departments. 
The new generation needs a new approach that grows out of the ground of Thai theater traditions, but out and into the fresh air. This approach should focus on the meaning of performances, art and traditions for today's performers and audiences. We still need to develop all the strengths of Thai traditional theater for people living today, considering their purpose and role with its more stagnant approaches. Thailand has developed ways to put smoothness and elegance onstage, but often more in order to make a big impression than to struggle with their underlying aims and to take part in the give and take of human communication.

Like Thai theater, theater in other parts of Asia is subject to changes in society and economy since it is so deeply rooted in ordinary people's lives. This leaves the door open to simpler productions and direct methods that can still convey complex truths to the hearts of Asian audiences. While wealthier countries can afford to create complex and refined works using the best in theater technologies and training methods, this is not possible for many in Asia at this time. What we are able to do at this time is to focus with the bodies, hearts, minds, rich tradiitons and limited technologies to reach today's audiences with issues and themes that reflect the problems and possibilities in today's societies in elegant and straightforward ways.

Today, traditional Thai theater-like much of traditional theater in Asia-needs practitioners more familiar with the wealth of the cultural resources available so that they can assemble, refine, and reassess them for stage pieces able to compel today's audiences. Artists need to balance the necessity to stand firmly in their cultural traditions and the demands to be open to new ideas and ways of interpreting their work. They also need to focus more on the purpose and significance of their work and their traditions to contemporary society. To date, modern interpretations have either refashioned traditional stories and themes for the contemporary stage, or selectively used formal elements from theater traditions onstage. Both approaches have tried to create pieces for the stage that compel, entertain, and challenge today's diverse audiences. In the future, performers will have to discover new ways to expand and enrich these approaches for tomorrow's audiences.

This is not something unique to those trained in classical dance-drama or folk traditions, but equally necessary for young theater practitioners more familiar with contemporary performance traditions. The crucial thing is for performers to search both within themselves and within the traditions around them to place new interpretations of traditional stories and new modes of presenting classically trained performers in stage pieces that can appeal to people living in today's world with today's problems and prospects. In this way the traditional performances can become once again a vital part of today's society and culture instead of the museum pieces reserved for ethnic ghettos that they are all too often now.

Young practitioners should be familiar with both the craft-like discipline demanded of artists in the classical and folk theater traditions and the creativity and excitement 
that characterize many folk and modern performance traditions. When challenged by both traditional priorities and contemporary pressures, young people have to learn to adapt creatively but with discipline and concentration. This challenge will result in more experimenting with those skilled in the traditional theater heritage, and will help create new kinds of theater pieces that successfully blend traditional discipline with modern creativity. More importantly, it will also point out the creativity of Thai (and Asian) traditions and the discipline of modern theater.

\section{Conclusions}

This essay has suggested that traditional theater in Asia is better seen as an interactive process between people and their culture rather than as a ghetto of ethnic performances sharply separated from the city of contemporary theater productions. Asian traditional theater takes shape wherever practitioners trained in a common body of theater traditions of a time, place and people meet to prepare and perform for audiences in order to entertain their eyes and ears as well as challenge their hearts and minds. In the last century more extensive governmental, corporate, technological, and media interests have reshaped the place of theater traditions in Thailand, replacing the court and community centers of a century ago.

This dynamic view of theater has helped me explore the developments of Thailand's garden of theater culture as a set of living traditions that adapted to the changing circumstances in the last hundred years.
Like the sharp divide between traditional and modern in general writings, performers have also tended to juxtapose distinct performance styles onstage or place familiar stories or characters in new settings. These two approaches led to a realization that excessive focus on form has led to a lack of concern for meaningful communication with audiences. Merely juxtaposing beautiful theater stories, characters, forms and bodies from different traditions onstage is not substantial enough for today's audiences, who seek more challenges from theater.

To address the form-rich but meaning-poor theater in Thailand, I have suggested a dual approach. This dual approach focuses on understanding the value, discipline and concentration central to old forms and communicate what you have learned with contemporary audiences. Besides making new efforts to strengthen the roots of our culture to touch the hearts and minds of performers and audiences in our own land, we also need to develop themes and collaborative ventures that can better enhance the growth of our cultural branches so they reach out and touch people living in other circumstances.

On the one hand, there is a great need for new ways to allow those trained in classical dance-drama, modern drama, and popular theater to communicate better among themselves in order to make new types of expressive art. On the other hand, there is a great need for these practitioners to find new ways to meaningfully communicate with today's audiences using the full range of cultural resources available. Reaching these basic goals will only come about if 
theater practitioners and scholars focus their knowledge and willpower on creating new productions that speak to today's diverse audiences.

In recent decades, various conventional ways of making productions and interacting onstage have already become standard in Thailand. Neither performers nor audiences find them exciting or challenging. Practitioners of these traditions still have much to learn about their own rich traditions and today's social and cultural realities. Younger audiences, especially, live in a world much more shaped by television, film, and music videos, and video games and are unfamiliar with older forms of public communication and entertainment. Reaching these people with our live theater heritage is a key goal if its traditions are to survive. This work will make a firmer foundation for productions in the next generation.

In the past thirty years substantive and stylistic differences have divided modern theater from popular culture, commercial shows from non-commercial theater, and spectacular productions from meaningful acting. There is nothing unique about this to Thailand or to other Asian countries. It is common to parallel tensions and possibilities in countries around the world. The broad sense of traditional theater discussed in this essay suggests a way to bridge these differences.

Traditional theater-understood as the living and ongoing negotiations between disciplined performers and unpredictable audiences that embody and enrich culture- is alive. While its health and prognosis in Thailand is somewhat more in doubt, there have been some promising developments in the last decade. Further improvements will emerge when performers and scholars contribute their knowledge and talent to reach audiences with hints at new or neglected aspects of the world and provocative acts that destabilize parts of the world that seem too stable. The more cooperation and coordination of their diverse efforts, the more effective and enduring their cultivation of Thailand's theater culture will be. Theater productions should remind audiences, through concrete and moving examples, that performers are both disciplined and creative, masters of craft and content, and purveyors of form and meaning. They should also show that their productions can be both true to older traditions' priorities of fun and beauty and also be compelling for audiences wanting to share in the new world they are making together with others interested in live theater today.

\section{References}

Appadurai, Arjun, et al. 1994. Expressive Traditions in South Asia. Philadelphia: University of Pennsylvania Press.

Damrhung, Pornrat. 1998. "The Roots of Future Blooming: Youth Theater in Thailand from the Twentieth to the Twenty First Century," Manusya: Journal of Humanities 1.2: 8-22.

Damrong Rajanubhab,Prince. 1984.Prachoom Prakat Rajkam thi 4 vol. 1. Bangkok: Kurusapa. 
Pattrachai, S; Damrhung, P; Wongprasert, C. 1997. Karnsadang Puenban Park Klang: Karn Prubpron nai Cheewit Thai Samai Mai [Folk Drama in Central Thailand: Adjustment to Modernization]. Research Report to the Thai Studies Institute of Chulalongkorn University (unpublished).

Poomsiri, Denduang. 1990. "Nuaythi 13: Karnsadang Puenban [Chapter 13: Folk Performance]." In Pasathai 8 [Thai Language 8]. Sukhothai: Faculty of Education, Sukhothai Thammathiraj University.

Tramote, Montri. 1984. Karn Lalen kong Thai [Thai Folk Performance] Krom Silpakorn, Bangkok.1961.

Rutnin, Mattani Mojdara. 1993. Dance, Drama, and Theater in Thailand: The Process of Development and Modernization. Tôkyô: Tôyô Bunkô. (rpt.Silkworm Books, 1996; Seattle: University of Washington, 1998).

Rutnin, Mattani Rutnin (ed.). 1975. The Siamese Theater. A Collection of Reprints from the Journals of the Siam Society. Bangkok: The Sompong Press, Ltd.

Virulrak, Surapone. 1997. Likay [Like] Bangkok: Office of the National Cultural Commission.

Virulrak, Surapone. 1999. "The Evolution of Thai Theater in Bangkok between 17821935," Manusya: Journal of Humanities 2.1: 69-82.

Wongthet, Sutjit. 1989. Rong Rum Tum Pleng [Singing, Dancing and Making Music] Bangkok: Silpawathananathum Printing Company.

\section{APPENDIX: New Traditional and New Cooperative Performances in Thailand (title of play, producer, year performed)}

\section{INDIVIDUAL PRODUCTIONS}

1. Lor Dilok Raj (Phirasri Arts Studio), 1987. The first modern spoken theater production based on an interpretation of an old Thai story. The tragic love story "Phra Lor" led to the death of three main characters: Phra Lor and the twin princesses Phra Puen and Phra Pang. The story was similar to Romeo and Juliet, which seldom appears in Thai literature.

2. Phra Sang / Ephigania (Chulalong- korn University's Dramatic Arts Department \& the Goethe Institut), 1988. This collaboration between Thai and German artists sought to create a single production based on the common aspects of two stories: the Thai "Sang Thong" (Golden Conch) and the ancient Greek story of Ephigenia. Using a German actress playing with professional Likay performers, with contempo- rary traditional music. Directed by Bruce Gaston.

3. Phra Suthon-Manohra (FAD) Thailand's Representative to the First ASEAN Theater Festival, 1989. This production used the traditional Bird folk dance of Maehongsorn province in north Thailand within the classical central court dance of Manohra, originally from the south. FAD.

4. Dearest Moon (Chulalongkorn University's Department of Dramatic Arts), 1990. Thailand's Representative to the Second ASEAN Theater Festival. A modern adaptation and expansion of a traditional Thai lullaby. Using modern 
social themes about young people with the traditional characters and classical dance and shadow puppets. Directed by Pornrat Damrhung.

5. Phuchana Sipthit (Conqueror of the Ten Directions) (FAD), 1990-1992. A Lakhon Phantang production based on a script of a Burmese story, this production used more spoken language and witty dialogue than usual, and relatively less dancing. Performed for two years running, it made several performers into superstars and changed the costume style and story of Lik a and Lakhon Thai. Directed by Seri Wangnaithum.

6. Kamupathan Khaki (Khon Lakorn), 1993 A new interpretation of the traditional story of Khaki, a female character who was blamed for her many lovers. It was modern spoken theater that used traditional dance drama performers in it in the roles of Garuda, and the Khon Tan musicians. Directed by Janaprakal Chandrueng.

7. Dang between Two Worlds, (Makhampom), 1993-1995. A modern touring theater for young people based on young girls as prostitutes in Thailand, using traditional dance and narrative story theater. Directed by Pradit Prasartthong.

8. Singhakraipob (Patravadi Theater) Thailand's Respresentative to the Third ASEAN Theater Festival, 1994. This was an attempt to make an old story into musical theater with songs and dances in modern style. Directed by Patravadi Meechuthon.

9. Phenomene: Sub Nakasatien (Ecru Music), 1995. A contemporary music concert with two pas de deux pieces of classical Thai dance-drama and ballet. Directed by Pornrat Damrhung and Sinnapa Sarasas.
10. Rahu Om Tawan (Fong Nam), 1995. A classical dance and contemporary musical performance at the time of the eclipse based on old Thai beliefs. Directed by Bruce Gaston and Leon Rubin.

11. Malai Monkol (Makhampom), 19951997. A touring theater production dealing with AIDS, using the old Malai chanting at the death ceremony and traditional dance on touring theater for young people including traditional music. Directed by Pradit Prasartthong.

12. Inao-Joraka (Patrivadi Theater), 1995. This used a traditional script of the classical Inao story with singing and traditional music combined with rockand-roll music and done in a musical style. Directed by Patravadi Meechuthon.

13. Ngor Pah (Patrivadi Theater), 1996. A musical and dance performance based on the traditional story by King Rama V. Directed by Patravadi Meechuthon.

14. Nithan Vetal (Moradok Mai), 1996. This is the attempt to combine the arts of the pop TV culture of game shows, contrasting with traditional characters. It also used young actors creating a confrontation between classical dance and pop TV atmosphere. Directed by Janaprakal Chandrueng.

15. Pimpilalai (Thailand's Cultural Center), 1996. Directed by Parichart Jungwiwattanaporn. The new interpretation of a traditional female character who was blamed for her reluctance to choose among her lovers. Using modern interpretation to present the old literature.

16. Savitri (DASS Entertainment), 1996. A traditional adaptation with modern Indian costumes and modern scenography and lighting for the 
Mahabharata story of Savitri written by King Rama VI.

17. Love and Death, based on Savitri by King Rama VI (Search Group), 1996. A dance theater piece using the confrontation of different art forms, including classical Khon dancers, contemporary dancers, ballet, and spoken theater actors. Directed by Pornrat Damrhung.

18. Sahatsadeja, (Patrivadi Theater), 1997. A new khon performance using performers from the Fine Arts Department, using modern shadow puppets. Directed by Julchart Arunyanar.

19. Lord Kankak (Moradok Mai), 1989 and 1997. The use of a traditional Isarn folk story for a young people's theater piece, using narrative techniques, modern shadow puppets and audience participation. Directed by Pornrat Damrhung.

20. Ku Chue Paya Pan (Crescent Moon), 1997. A Thai version of a folk story from Nakorn Prathom that is similar to Oedipux Rex, concentrating on mask and movement. Directed by Kamron Khunadilok.

21. Love of Khaki (Dance Center), 1997. A collaborative ballet and classical Thai dance performance of a classical story. Directed by Somthao Sanit.

22. Kong Khao Noi (Patrivadi), 1997. The Butoh performer Katsura Kan directed a piece based on an Isarn folk story using film, video and audience participation to look at the views of a son killing his mother. Directed by Katsura Kan.

23. Kamar Chalawan (Rajapatra Institute), 1997. A new traditional production of the Pichit Province folk story "Kraithong" that deals with the fighting a hero with a crocodile. Performed on a floating stage using classical dance interspersed with modern movements. Directed by Pichet Klunchuen.

24. Archeep Khong Mae (adapted from Bernard Shaw's "Mrs. Warren's Profession"; Department of Dramatic Arts / Chulalongkorn University). A research theater piece emphasizing the theme and allowing the audience to comment on the play. Directed by Nikorn Tang.

25. NONTOOK (Chulalongkorn University's Department of Academic Affairs), 1998. An experimental research on new traditional performance practice using the Ramakien text, and concentrating on the theme of Power, peeling away all decorations of classical and modern traditions. Collabortive work by Pornrat Damrhung, Pichet Klunchuen, and Dangkamol $\mathrm{Na}$ Pombejara.

26. Pink Elephant (Chulalongkorn University's Department of Dramatic Arts), 1998. A contemporary Butoh piece that dealt with the life process, loosely adopting aspects from Japanese and Thai culture. Directed by Katsura Kan.

27. Chaou Jan Pom Hom (Moradok Mai), 1998. A modern theater piece based on a SEA-Write award-winning story about women in traditional and modern roles that used much traditional dance and narrative singing. Directed by Janaprakal Chandrueng.

28. Suthon Manohra (Moradok Mai), 1998. A contemporary interpretation of the old Manorah story, placing the bird-woman in a film production studio using a lot of southern instrumentation and southern style of dancing. Directed by Janaprakal Chandrueng.

29. Phra Apaimanee torn Nee Pheesue Samutra (Seminar and Workshop in the Preservation and Development of Thai 
Folk Performance, Thailand Cultural Commission), 1998. A short experimental collaboration of a Lakhon Phantang piece using a classical Khon artist and a professional Lakhon Thai artist, with Pichet Klunchuen as a mother seademon and Sumon Rongrueng Silpa as her son Sin Samutra.

30. Akaoni (Japan Cultural Center), 19981999. A collaborative theater project using Japanese and Thai actors based on an original story by the director Noda Hideki.

31. The Death of Empedocles (The French Embassy in Thailand with the support of the AFAA), 1999. A collaboration between a French theater producer, a Japanese Butoh dancer, a cast of French and Thai performers using Thai contemporary Thai music and words. Directed by Philippe Lanton.

32. A) Demon's First Date \& B) Love Story (APPEX, UCLA), 1999. A) Presentation on the basic techniques of the Giant role in Thai Khon. Danced by Pichet Kluncheun. B) A dance piece based on a Javanese folk story with Japanese chanting and music with a chorus of ten from different countries. Danced by Pichet Klunchuen and Amiko Mitoma.

\section{GROUP INITIATIVES}

The Patravadi Theater has organized an annual Fringe Theater Festival in Bangkok during March and April since 1998. Nimit Pipititkul organized the 1999 festival and will organize the upcoming festival in 2000 to include demonstrations, workshops and performances. 